The Extent of Federalism in Uganda

Labour Protest in Kenya, the Early Phase: 1914-39

D. S. Rothschild

Labour Problems

An Outline of Resettlement Policy in Uganda: $1945-63$

Some Legal Aspects of Land Reform in Kenya

Kenyans in Busoga

Counter Revolution to Mau Mau: Land Consolidation in Kikuyuland, $1952-60$

Education Research

Future of Primary Leavers in Uganda

Aspirations and Problems of Nigerian School Leavers

Formal and Informal Learning through the Medium of a Second Language

A Look at Selected Student Autobiographies

D. C. Savage

D. G. R. Belshaw

H. Fliedner

S. Illingworth

M. P. K. Sorrenson

F. K. Kamoga

A. J. McQueen

J. Silvey

S. G. Weeks

The Administrative Secretary, EAISR, Makerere College, P.O. Box I6022, Kampala, Uganda, will supply single papers at Shs. 2 or its equivalent, and complete Parts at Shs. 6 or its equivalent.

\title{
Université de Dakar: Institut Frangais d'Afrique Noire
}

Monsieur Samba N'Diaye est entré à l'IFAN en 1963 comme responsable du laboratoire d'ethnographie, qui dépend du département de Sociologie. Il procède actuellement à une enquête sur la culture matérielle des Serer, au Sénégal central et a déjà acquis et étudié un matériel ethnographique relatif aux techniques d'acquisition: pêche, chasse, cueillette, élevage et agriculture.

\section{Committee on African Studies in Canada}

The Committee on African Studies in Canada (see Africa, July 1963, p. 266), established at the end of 1962 and temporarily affiliated with the Social Science and Humanities Research Councils of Canada, has appointed a special Sub-committee for the Development of an Africanist Study and Research Centre for Canada. It is hoped to co-ordinate and consolidate the scattered resources of the country in order (a) to encourage the study of Africa by many disciplines at the undergraduate (pre-B.A.) level in Canadian universities, and (b) to develop at one or two places in the country a staff and facilities for advanced research and study of Africa. Co-operation and complementary if not completely co-ordinated development are hoped for among both the English-speaking and the French-speaking universities in Canada. The Chairman of the Committee is Dr. D. L. Wiedner, Department of History, University of Alberta, Edmonton, Alberta. Dr. Wiedner is also the Editor of the biannual Bulletin of the Committee which is published in English and French. The first issue appeared in November ${ }^{9}{ }^{6} 3$.

\section{Istituto per le Civiltà Primitive, Università di Roma}

A course on African studies, 'Civiltà Indigene dell'Africa', is now included as an optional subject in the syllabus of the Scuola di Perfezionamento in Scienze Etnologiche postgraduate programme of Rome University. A certificate is awarded at the end of the second year. The Scuola is attached to the Institute, but its staff is drawn from the University of Rome as a whole. The Director of the Institute, Professor Grottanelli, has done field research among the Nzema of south-western Ghana in $1954,196 \mathrm{I}-2$, and 1963 , on the second occasion assisted by Dr. E. Cerulli and Signor S. Natonek. It is expected that research in this 